\title{
Evaluation of the Alter-Rater Model for Timing of Fungicide Applications for Control of Alternaria Brown Spot of Citrus
}

\author{
Alka Bhatia, Senior Biological Scientist, University of Florida, Citrus Research and Education Center, Lake Alfred \\ 33850, P. D. Roberts, Assistant Professor, University of Florida, Southwest Florida Research and Education Center, \\ Immokalee 34142, and L. W. Timmer, Professor, University of Florida, Citrus Research and Education Center, \\ Lake Alfred 33850
}

\begin{abstract}
Bhatia, A., Roberts, P. D., and Timmer, L. W. 2003. Evaluation of the Alter-Rater model for timing of fungicide applications for control of Alternaria brown spot of citrus. Plant Dis. 87:1089-1093.

Alternaria brown spot, caused by Alternaria alternata, results in serious yield losses of tangerines and their hybrids in Florida. The Alter-Rater model predicts the need for fungicide applications based on daily cumulative points that are assigned on the basis of rainfall, leaf wetness, and temperature. Previously, Alter-Rater threshold or trigger values of 50, 75, 100, and 150 points for application of copper fungicides were suggested for groves with different cultivars and disease histories. In this study, we evaluated thresholds of 50,100, and 150 points in four Minneola tangelo and Murcott tangor groves in 2000 and 2001. For comparison, copper fungicides were applied according to the DISC Copper Model in 2000 and according to calendar sprays in 2001. Use of the Alter-Rater model resulted in fewer sprays in three of the four groves in 2000 and better fruit quality in the other grove than the Copper Model. Compared to a calendar spray schedule in 2001, use of the Alter-Rater model resulted in fewer sprays in two of the four groves but more sprays in one grove. The results confirmed that the Alter-Rater is a valuable tool for timing fungicide applications and that its use results in better disease control or fewer sprays.
\end{abstract}

Alternaria brown spot (ABS) is a serious disease of tangerines and their hybrids in Florida and other humid and semiarid growing regions (19). The causal agent was described originally as Alternaria citri Ellis \& Pierce (13) and later renamed $A$. alternata (Fr:Fr) Keissl. pv. citri (16). Simmons (15) has described 10 new species from a worldwide collection of Alternaria isolates from citrus, including two species from tangelo in Florida. Based on extensive molecular studies, Peever et al. $(11,12)$ found that all small-spored Alternaria isolates from citrus are similar and suggested use of A. alternata. Alternaria brown spot was first identified in central Florida on Dancy tangerines in 1974 (24). The disease now occurs statewide in most groves of susceptible cultivars. Florida has about 19,000 ha of tangerine and tangerine hybrids, about two- thirds of which are

Corresponding author: L. W. Timmer E-mail: 1wt@1al.ufl.edu

This research was supported by the Florida Agricultural Experiment Station and a grant from the Florida Citrus Production Research Advisory Council, project 013-16P and approved for publication as Journal Series No. R-09189.

Accepted for publication 6 April 2003.

Publication no. D-2003-0623-01R

(C) 2003 The American Phytopathological Society planted to susceptible cultivars such as Minneola and Orlando tangelos, Murcott tangor, Dancy tangerine, and hybrids of Dancy such as Sunburst, Nova, and Lee (3).

Alternaria brown spot causes small black necrotic spots on young leaves, twigs, and fruit, 24 to $48 \mathrm{~h}$ after infection (20). The pathogen produces a host-specific toxin (6) that causes lesions to expand, often resulting in leaf and fruit drop and twig dieback. On mature fruit, lesions may vary from small necrotic spots to large, sunken pock marks that spoil the appearance of fruit destined for the fresh market. Leaves are susceptible to infection from the time of formation until they are fully expanded and hardened, and fruit are susceptible from petal fall until they reach about $5 \mathrm{~cm}$ in diameter (20), which is usually mid to late July in Florida. This disease may affect tree growth, cause considerable crop loss, and produce blemishes on fresh fruit that are unacceptable to the consumer. All tangerines and their hybrids in Florida are produced for the fresh market, and the fruit used for processing has little value (3).

Release of conidia of A. alternata on citrus is triggered by rainfall events and by sudden changes in relative humidity (18). In Florida, optimum conditions for infection are temperatures from 23 to $27^{\circ} \mathrm{C}$ and 8 to $12 \mathrm{~h}$ of continuous leaf wetness $(1,21)$. Cultural measures, such as wider tree spac- ing, elimination of overhead irrigation, and avoidance of excess nitrogen fertilizer and water have helped reduce disease severity in some groves $(17,19)$. However, fungicide applications are essential for disease control and production of blemish-free fruit. Copper fungicides and strobilurin fungicides are recommended for control of Alternaria brown spot (22). Growers may apply from three to ten fungicide sprays during the course of a growing season, depending on disease history and variety planted. Without fungicide applications, losses of marketable fruit would be severe in many groves.

Considerable research has been conducted on Alternaria diseases of potato and tomato. A number of predictive models, such as EPIDEM, FAST, and some newer models, have been developed $(4,8,14,23)$ to aid in timing fungicide sprays. Predictive models are also available for Alternaria diseases on apples (2) and carrots (5), and for Stemphylium vesicarium on pears (9). These systems either involve annual crops or temperate, deciduous fruits in which epidemics develop within the course of a year. In Florida citrus, Alternaria brown spot becomes endemic in the grove, and the period during the year when the pathogen is inactive is relatively short. Thus, models developed for other crops provide little assistance in developing spray programs for citrus.

A study of the detailed relationships between environmental factors and Alternaria brown spot severity on citrus led to the development of the Alter-Rater model by Timmer et al. (21). Alter-Rater is a weatherbased model for timing fungicide sprays for Alternaria brown spot control. A point value from 0 to 11 is assigned to each day depending on three weather factors: (i) rainfall more or less than $2.5 \mathrm{~mm}$, (ii) leaf wetness more or less than $10 \mathrm{~h}$, and (iii) average daily temperature below $20^{\circ} \mathrm{C}$, between 20 and $28^{\circ} \mathrm{C}$, or greater than $28^{\circ} \mathrm{C}$ (21). The point values are accumulated on a daily basis until the total reaches the predefined trigger value. A spray application is then made. In this paper, we evaluate the trigger values previously suggested for use of the Alter-Rater model and compare the Alter-Rater with two other methods of timing fungicide applications - the DISC Copper Model (7) and a calendar spray schedule. The DISC Copper Model 
is based on depletion of copper residues by fruit enlargement and rainfall. It was primarily designed for timing sprays for melanose (pathogen Diaporthe citri) on grapefruit, but the DISC Copper Model has fruit growth curves for tangerines as well. Since copper fungicides are used for both melanose and Alternaria brown spot, it was expected that the Copper Model would provide useful predictions for both diseases. We also compare the cost and returns of utilizing the Alter-Rater versus the two other methods of spray timing.

\section{MATERIALS AND METHODS}

The Alter-Rater model was tested during the growing season (mid-March to midJuly) in four locations in Florida in 2000 and 2001, using three of the four trigger values suggested previously (21): 50 points (Alt 50), 100 points (Alt 100), and 150 points (Alt 150). Point values were assigned to each day based on the combination of the three weather variables (Table 1). The points were accumulated daily until a specified threshold value (50 points, 100 points, or 150 points) was reached, at which time a fungicide application was made. Treatments were assigned to trees in each grove in a randomized complete block design consisting of five replications of two trees each. Each plot was separated by an unsprayed guard tree, which served as a buffer between plots. 2001, sprays were applied in four grovesa severely infested Minneola tangelo (Citrus reticulata Blanco $\times C$. paradisi Macf.) grove in Polk City, a moderately infested Minneola tangelo grove in Lake Alfred, a moderately infested Murcott tangor $(C$. reticulata $\times C$. sinensis (L.) Osb.) grove in Frostproof, and a mildly infested Orlando tangelo grove in Immokalee. On a disease rating scale of 0 to 5 , a mildly infested grove was defined as having a rating of less than 1.5, a moderately infested grove a rating of 1.5 to 2.5 and a severely infested grove a rating above 3 on unsprayed fruit. Mild, moderate, and severely infested groves were categorized based on Alternaria brown spot fruit ratings from previous years and from a general visual inspection of Alternaria brown spot severities in
Locations and treatments. In 2000 and

the groves. Sprays timed according to the Alter-Rater model were compared with those sprays applied according to the DISC Copper Model (7) in 2000. Since the Copper Model was not very effective at all locations in 2000, we decided to use a calendar schedule as our standard for comparison to the Alter-Rater in 2001. All fungicide applications were made with copper hydroxide (Kocide 2000, Griffin LLC, Valdosta, GA) at $4.5 \mathrm{~kg} / \mathrm{ha}$ using a handgun sprayer at $14.1 \mathrm{~kg} / \mathrm{m}^{2}$, and trees were sprayed to run-off. An initial application was made to all plots in the Alter-Rater treatments when the spring growth flush of leaves was one-third to one-half expanded, regardless of threshold. In 2000, the initial sprays in Alter-Rater treatments were made on 16 March in Lake Alfred, 20 March in Polk City, 14 March in Frostproof, and on 21 March in Immokalee; and in 2001, the initial sprays in the Alter-Rater treatments were made on 5 Mar in Lake Alfred and Polk City, 8 Mar in Frostproof, and 23 Feb in Immokalee. All subsequent sprays were based on the Alter-Rater model. Since the Copper Model predicts sprays based on fruit growth, it cannot be utilized until petal fall. Thus, the first two sprays were made automatically when the spring flush was one-third to one-half expanded and at petal fall, and the Copper Model was used thereafter. The spring flush treatments of the Copper Model in 2000 were applied on the same dates as the Alter-Rater treatments. Petal fall sprays in the Copper Model treatment were applied on 12 April in Lake Alfred and Polk City, on 10 April in Frostproof, and 4 May in Immokalee. In 2001, the initial sprays in the calendarbased schedule were applied on the same dates as those for the initial Alter-Rater sprays and every 3 weeks thereafter in all groves, except the heavily infested grove in Polk City, where applications were made every 2 weeks. No applications were made after 15 July, when the fruit became resistant to further infection by Alternaria brown spot. Weather data were obtained from AdCon weather stations operated by ProSource One (Agrilink Holdings Inc., Alva, FL) and from the Florida Automated Weather Network (University of Florida), all located within $500 \mathrm{~m}$ of each grove.

Table 1. The daily scores assigned by the Alter-Rater model to various combinations of rainfall, leaf wetness, and temperature (18)

\begin{tabular}{cccc}
\hline Rainfall > 2.5 $\mathbf{~ m m}$ & Leaf wetness $>\mathbf{1 0} \mathbf{~ h}$ & Avg daily temperature $\left({ }^{\circ} \mathbf{C}\right)$ & Assigned score \\
\hline+ & + & 20 to 28 & 11 \\
+ & + & $>28$ & 8 \\
+ & + & $<20$ & 6 \\
+ & $20-28$ & 6 \\
+ & $>28$ & 4 \\
+ & - & $<20$ & 3 \\
- & - & $20-28$ & 6 \\
- & + & $>28$ & 6 \\
- & + & $20-28$ & 4 \\
- & + & $>28$ & 3 \\
- & - & $<20$ & 0 \\
- & - & & 0 \\
\hline
\end{tabular}

Disease assessment. In September or October of each year, severity of Alternaria brown spot was rated visually on up to 50 arbitrarily selected fruit per tree, depending on fruit availability. A scale of increasing disease severity ranging from 0 to 5 was used. A rating of zero indicated no symptoms, $1=1$ to 2 small lesions, $2=3$ to 5 lesions, $3=6$ to 10 lesions, $4=11$ to 15 lesions, and $5=$ more than 15 lesions. The percentage of marketable fruit was calculated for each treatment. Fruit with no or 1 to 2 small lesions (rating of 0 or 1 ) was considered acceptable for the fresh market. Disease severity ratings and the percentages of marketable fruit were subjected to analysis of variance and the means were separated by the Waller-Duncan $k$-ratio $t$ test $(P \leq 0.05)$. The number of sprays, days between sprays, and average number of Alter-Rater model points between sprays were also summarized for the different treatments in each location.

Economic analysis. The number of sprays and degree of disease control, as defined by average disease rating and percentage pack-out, varied among treatments. A cost-benefit analysis was conducted to determine the relationship between number of sprays for Alternaria brown spot control and increased pack-out. The most recent grower-estimated yield per hectare for each cultivar, the price per box of fresh and processing fruit (3), and the cost of spray applications per hectare (10) were obtained. The difference in price per box between fresh and processing fruit was used in assessing the dollar value of obtaining fruit acceptable for the fresh market.

Economic comparisons were made between the preselected trigger value that would be suggested based on previous studies (21) and compared with the Copper Model in 2000 and the calendar schedule in 2001. Based on the susceptibility of the cultivar and the disease history, the suggested trigger values were Alt 50 in Polk City, Alt 100 in Lake Alfred and Frostproof, and Alt 150 in Immokalee. AlterRater thresholds for each location were chosen based on criteria defined by Timmer et al. (21), namely, disease history in the grove, varietal susceptibility, and the location of the grove.

The benefit of different spray treatments at each location was determined by comparing the number of sprays in a treatment with the corresponding percent increase or decrease in fresh fruit pack-out. The corresponding net financial gain with an $x \%$ increase in fresh fruit was calculated by subtracting the cost of additional sprays from the overall gross returns.

\section{RESULTS}

Spray intervals and frequencies. In both years, use of the Alt 50 trigger value resulted in the greatest number of sprays and the best disease control among AlterRater treatments (Tables 2 and 3). The Alt 
100 required as few as five sprays to as many as ten, and the Alt 150 spray frequency ranged from four to seven sprays in the season. The Copper Model in 2000 required six to eight sprays, and the calendar schedule in 2001 required seven to ten sprays (Tables 2 and 3).

There was a wide range in spray intervals among the treatments (Tables 2 and 3). The shortest spray interval for each Alter-Rater treatment was a direct function of increasing trigger values. The differences in spray intervals for the same treatment in different locations and years were a result of daily weather differences between locations during the growing season. Calendar spray intervals were consistent. The average number of points between sprays fell within a range close to the trigger values. Logistical problems prevented spraying on the exact date indicated, but actual applications corresponded well to those indicated in both years (Tables 2 and $3)$.

2000. In Polk City, Alternaria brown spot was severe (Table 2). All treatments significantly reduced disease ratings and increased the percent marketable fruit com- pared with the unsprayed control. The Alt 50 treatment produced the best control. The Alt 150 treatment and the Copper Model worked equally well, but the Alt 150 used half the number of sprays. Disease was comparatively less severe in Lake Alfred. All treatments in Lake Alfred significantly reduced disease and, except the Alt 150, all increased marketable fruit compared with the control. The Copper Model used more sprays than the Alt 100 and Alt 150 but provided no better control. In Frostproof, the percentage of marketable fruit was not significantly different among

Table 2. Effect of different trigger values for the Alter-Rater model on the number and timing of copper fungicide sprays and control of Alternaria brown spot in 2000

\begin{tabular}{|c|c|c|c|c|c|c|}
\hline $\begin{array}{l}\text { Location } \\
\text { (Cultivar) }\end{array}$ & Treatment & Number of sprays & $\begin{array}{c}\text { Range of time } \\
\text { between sprays (days) }\end{array}$ & $\begin{array}{l}\text { Avg no. of points } \\
\text { between sprays }\end{array}$ & $\begin{array}{l}\text { Mean disease severity } \\
\text { rating ( } 0 \text { to } 5)\end{array}$ & $\begin{array}{c}\text { Mean marketable } \\
\text { fruit }(\%)\end{array}$ \\
\hline Polk City & Unsprayed control & 0 & - & - & $3.31 \mathrm{a}^{\mathrm{x}}$ & $6.8 \mathrm{c}^{\mathrm{y}}$ \\
\hline \multirow[t]{4}{*}{ (Minneola) } & Alt $50^{\mathrm{z}}$ & 10 & 4 to 28 & 47 & $1.58 \mathrm{c}$ & $61.0 \mathrm{a}$ \\
\hline & Alt100 & 5 & 19 to 39 & 104 & $1.95 \mathrm{~b}$ & $37.3 \mathrm{~b}$ \\
\hline & Alt150 & 4 & 25 to 44 & 139 & $1.94 \mathrm{~b}$ & $39.4 \mathrm{~b}$ \\
\hline & $\mathrm{Cu}$ model & 8 & 4 to 26 & 84 & $1.94 \mathrm{~b}$ & $45.4 \mathrm{~b}$ \\
\hline Lake Alfred & Unsprayed control & 0 & - & - & $1.89 \mathrm{a}$ & $51.6 \mathrm{~b}$ \\
\hline \multirow[t]{4}{*}{ (Minneola) } & Alt50 & 8 & 9 to 21 & 55 & $0.97 \mathrm{~b}$ & $81.6 \mathrm{a}$ \\
\hline & Alt $100^{z}$ & 5 & 20 to 33 & 97 & $1.04 \mathrm{~b}$ & $85.1 \mathrm{a}$ \\
\hline & Alt150 & 4 & 30 to 45 & 144 & $1.22 \mathrm{~b}$ & $68.8 \mathrm{ab}$ \\
\hline & $\mathrm{Cu}$ model & 6 & 14 to 41 & 87 & $1.07 \mathrm{~b}$ & $79.1 \mathrm{a}$ \\
\hline Frostproof & Unsprayed control & 0 & - & - & $1.16 \mathrm{a}$ & $76.2 \mathrm{~b}$ \\
\hline \multirow[t]{4}{*}{ (Murcott) } & Alt50 & 12 & 5 to 14 & 46 & $0.65 \mathrm{c}$ & $96.7 \mathrm{a}$ \\
\hline & Alt $100^{z}$ & 6 & 13 to 29 & 98 & $0.73 b c$ & $96.2 \mathrm{a}$ \\
\hline & Alt150 & 4 & 25 to 43 & 153 & $0.80 \mathrm{~b}$ & $92.4 \mathrm{a}$ \\
\hline & $\mathrm{Cu}$ model & 8 & 7 to 26 & 82 & $0.75 \mathrm{bc}$ & $92.4 \mathrm{a}$ \\
\hline Immokalee & Unsprayed control & 0 & - & - & $0.99 \mathrm{a}$ & $92.7 \mathrm{~b}$ \\
\hline \multirow[t]{4}{*}{ (Orlando) } & Alt50 & 10 & 8 to 18 & 57 & $0.51 \mathrm{~d}$ & $100.0 \mathrm{a}$ \\
\hline & Alt100 & 6 & 9 to 27 & 99 & $0.75 \mathrm{bc}$ & $98.0 \mathrm{ab}$ \\
\hline & Alt $150^{z}$ & 4 & 24 to 36 & 157 & $0.87 \mathrm{ab}$ & $96.3 \mathrm{ab}$ \\
\hline & $\mathrm{Cu}$ model & 6 & 10 to 43 & 112 & $0.66 \mathrm{c}$ & $97.3 \mathrm{ab}$ \\
\hline
\end{tabular}

${ }^{\mathrm{x}}$ Mean separation by the Waller-Duncan $k$-ratio $t$ test, $P \leq 0.05$, to determine differences in disease severity between treatments at each location.

y Mean separation by the Waller-Duncan $k$-ratio $t$ test, $P \leq 0.05$, to determine differences in marketable fruit between treatments at each location.

${ }^{\mathrm{z}}$ Suggested trigger value based on previous studies (18).

Table 3. Effect of different trigger values for the Alter-Rater model, on the number and timing of copper fungicide sprays and control of Alternaria brown spot in 2001

\begin{tabular}{|c|c|c|c|c|c|c|}
\hline $\begin{array}{l}\text { Location } \\
\text { (Cultivar) }\end{array}$ & Treatment & Number of sprays & $\begin{array}{c}\text { Range of time between } \\
\text { sprays (days) }\end{array}$ & $\begin{array}{l}\text { Avg no. of points } \\
\text { between sprays }\end{array}$ & $\begin{array}{c}\text { Mean disease } \\
\text { severity rating }(0-5)\end{array}$ & $\begin{array}{c}\text { Mean marketable } \\
\text { fruit }(\%)\end{array}$ \\
\hline Polk City & Unsprayed control & - & - & - & $2.41 \mathrm{a}^{\mathrm{v}}$ & $16.9 \mathrm{c}^{\mathrm{w}}$ \\
\hline \multirow{4}{*}{ (Minneola) } & Alt50 $0^{\mathrm{x}}$ & 13 & 8 to 13 & 52 & $0.46 \mathrm{~d}$ & $98.2 \mathrm{a}$ \\
\hline & Alt100 & 7 & 17 to 27 & 112 & $0.97 \mathrm{~b}$ & $84.9 \mathrm{~b}$ \\
\hline & Alt150 & 5 & 20 to 36 & 154 & $1.00 \mathrm{~b}$ & $83.5 \mathrm{~b}$ \\
\hline & Calendar ${ }^{\mathrm{y}}$ & 10 & 10 to 17 & 72 & $0.74 \mathrm{c}$ & $95.1 \mathrm{a}$ \\
\hline Lake Alfred & Unsprayed control & 0 & - & - & $3.2 \mathrm{a}$ & $12.0 \mathrm{~d}$ \\
\hline \multirow[t]{4}{*}{ (Minneola) } & Alt50 & 10 & 7 to 24 & 52 & $0.66 \mathrm{c}$ & $93.2 \mathrm{a}$ \\
\hline & Alt100 & 6 & 16 to 38 & 103 & $0.96 \mathrm{c}$ & $85.1 \mathrm{ab}$ \\
\hline & Alt150 & 4 & 27 to 55 & 150 & $1.45 \mathrm{~b}$ & $58.0 \mathrm{~d}$ \\
\hline & Calendar $^{\mathrm{z}}$ & 7 & 17 to 23 & 82 & $0.99 \mathrm{c}$ & $71.6 \mathrm{bc}$ \\
\hline Frostproof & Unsprayed control & 0 & - & - & $1.14 \mathrm{a}$ & $78.2 \mathrm{c}$ \\
\hline \multirow[t]{4}{*}{ (Murcott) } & Alt50 & 10 & 9 to 18 & 53 & $0.30 \mathrm{c}$ & $98.4 \mathrm{a}$ \\
\hline & Alt100 & 6 & 13 to 29 & 100 & $0.37 \mathrm{c}$ & $98.6 \mathrm{a}$ \\
\hline & Alt150 & 4 & 28 to 48 & 153 & $0.59 \mathrm{~b}$ & $92.8 \mathrm{~b}$ \\
\hline & Calendar ${ }^{\mathrm{z}}$ & 7 & 18 to 21 & 84 & $0.29 \mathrm{c}$ & $98.6 \mathrm{a}$ \\
\hline Immokalee & Unsprayed control & 0 & - & - & $1.24 \mathrm{a}$ & $72.5 \mathrm{~b}$ \\
\hline \multirow[t]{4}{*}{ (Orlando) } & Alt50 & 16 & 6 to 13 & 55 & $0.82 \mathrm{~b}$ & $90.1 \mathrm{a}$ \\
\hline & Alt100 & 10 & 11 to 18 & 101 & $0.72 \mathrm{bc}$ & $95.8 \mathrm{a}$ \\
\hline & Alt150 & 7 & 19 to 27 & 154 & $0.51 \mathrm{c}$ & $98.6 \mathrm{a}$ \\
\hline & Calendar ${ }^{\mathrm{z}}$ & 7 & 18 to 21 & 132 & $0.70 \mathrm{bc}$ & $96.6 \mathrm{a}$ \\
\hline
\end{tabular}

\footnotetext{
${ }^{\mathrm{v}}$ Mean separation by the Waller-Duncan $k$-ratio $t$ test, $P \leq 0.05$, to determine differences in disease severity between treatments at each location.

${ }^{\text {w }}$ Mean separation by the Waller-Duncan $k$-ratio $t$ test, $P \leq 0.05$, to determine differences in marketable fruit between treatments at each location.

${ }^{x}$ Suggested trigger value based on previous studies (18).

y Calendar schedule applications every 2 weeks.

${ }^{\mathrm{z}}$ Calendar schedule applications every 3 weeks.
} 
spray treatments. However, disease ratings were slightly lower in the Alt 50 . The Copper Model worked as well as the Alt 100 or Alt 150 but used more sprays. Alternaria brown spot severity on Orlando tangelo was low in Immokalee. Only the Alt 50 with ten sprays significantly increased the percentage of marketable fruit compared with the control. All treatments except the Alt 150 significantly reduced disease severity.

2001. The Polk City grove had high disease pressure again this year (Table 3 ). The Alt 100 and Alt 150 worked equally well but with about $10 \%$ less marketable fruit than that with the other two treatments. In Lake Alfred, disease pressure was very high on the Minneola tangelos. The Alt 50, Alt 100, and calendar schedule were effective in reducing disease severity and increasing marketable fruit significantly. On the Murcotts in Frostproof, disease levels were fairly low and very similar to the disease levels in Immokalee. The control yielded close to $80 \%$ marketable fruit. All treatments except the Alt 150 were very effective. The Alt 150 reduced disease levels to only half that of the control and produced significantly fewer marketable fruit than the other treatments. The Immokalee grove had fairly low disease levels on the Orlando tangelos. All four spray treatments worked equally well in reducing brown spot severity and in increasing marketable fruit from $72 \%$ in the control to 90 to $98 \%$ among the four spray treatments. The Alt 150 and the calendar program worked equally well and used the fewest sprays.

Table 4. A comparison of yields and prices for fresh and processing fruit

\begin{tabular}{|c|c|c|c|c|c|}
\hline \multirow[b]{2}{*}{ Cultivar } & \multirow[b]{2}{*}{ Yield $^{w}$} & \multicolumn{2}{|c|}{ Price per box ${ }^{x}$} & \multirow[b]{2}{*}{ Difference } & \multirow[b]{2}{*}{ Added profit/hay } \\
\hline & & Fresh & Processing & & \\
\hline Minneola tangelo & 500 & $\$ 12.50$ & $\$ 1.06$ & $\$ 11.44$ & $\begin{array}{l}1 \% \times 500 \text { boxes } \times \$ 11.44= \\
\$ 57.20\end{array}$ \\
\hline Orlando tangelo & 1,000 & $\$ 5.15$ & $\$ 1.06$ & $\$ 4.09$ & $\begin{array}{l}1 \% \times 1000 \text { boxes } \times \$ 4.09= \\
\$ 40.90\end{array}$ \\
\hline Murcott tangor & 1,125 & $\$ 16.60$ & $-\$ 0.11^{z}$ & $\$ 16.71$ & $\begin{array}{l}1 \% \times 1125 \text { boxes } \times \$ 16.71= \\
\$ 188.00\end{array}$ \\
\hline
\end{tabular}

${ }^{\mathrm{w}}$ Measured in approximate number of boxes per ha. A box contains about $40 \mathrm{~kg}$ of fruit.

x From Florida Agricultural Statistics Service (3), numbers are based on 2000-2001.

${ }^{y}$ For each $1 \%$ increment in fruit converted from processing to fresh.

${ }^{\mathrm{z}}$ Negative values are attributable to surcharges imposed by the packinghouse for handling eliminations.

Economics. Groves treated following a spray schedule predicted by the Alter-Rater model proved to be profitable in all four groves in 2000 and in two of the four groves in 2001 (Tables 4 and 5). Returns on the cultivars used in these studies were much greater for fresh fruit than for procfruit. In Polk City in 2000, only the Alt 50 with ten sprays was able to control disease well enough to produce over truit. Two more sprays were required by the Alt 50 as compared we Copper Model, but the two extra per \$703 per ha. In Lake Alfred, the Alt 100 was the best choice and saved $\$ 93$ per ha Coppray compared with the wix sprays, provided equivalent sprays or $\$ 186$ per ha in costs. In Immokalee, the Alt 150 performed as well as the other treatments but used the fewest sprays. The Alt 150 used two fewer sprays than the Copper Model to produce the same level of control, thus saving \$186 per ha in spray costs.

In 2001, the Alter-Rater performed as well or better than the calendar schedule, (Table 5). In Polk City, ten sprays in the calendar schedule prodimilar levels of marketable fruit to evels were very high in this grove, and we chose to use the calendar schedule every 2 weeks other locations and, as a result, the calendar schedule proved to be even more effective than the chosen Alter-Rater threshold. Copper Model. In Frostproof, the Alt 100,

Table 5. Recommended spray treatments for locations and the costs and benefits compared with the Copper Model (2000) or calendar spray schedule (2001)

\begin{tabular}{|c|c|c|c|c|c|c|c|c|c|}
\hline \multirow[b]{2}{*}{ Location } & \multirow[b]{2}{*}{$\begin{array}{c}\text { Cultivar } \\
\text { (susceptibility) }\end{array}$} & \multirow[b]{2}{*}{ Inoculum levels } & \multirow[b]{2}{*}{$\begin{array}{c}\text { Recommended } \\
\text { threshold }\end{array}$} & \multicolumn{3}{|c|}{2000} & \multicolumn{3}{|c|}{2001} \\
\hline & & & & Sprays $^{x}$ & $\%$ fresh $^{y}$ & $\begin{array}{l}\text { Profit }(+) \\
\text { or loss }(-)^{\mathrm{z}}\end{array}$ & Sprays & $\%$ fresh & $\begin{array}{l}\text { Profit (+) } \\
\text { or loss (-) }\end{array}$ \\
\hline Polk City & Minneola (high) & High & Alt 50 & +2 & $+15.6 \%$ & $+\$ 703$ & +3 & NS & $-\$ 279$ \\
\hline Lake Alfred & Minneola (high) & Moderate & Alt 100 & -1 & NS & $+\$ 93$ & -1 & NS & $+\$ 93$ \\
\hline Frostproof & Murcott (moderate) & Low to moderate & Alt 100 & -2 & NS & $+\$ 186$ & -1 & NS & $+\$ 93$ \\
\hline Immokalee & Orlando (moderate) & Moderate & Alt 150 & -2 & NS & $+\$ 186$ & 0 & NS & 0 \\
\hline
\end{tabular}

${ }^{\mathrm{x}}$ Number of sprays more (+) or less (-) than the Copper Model (2000) or calendar schedule (2001). Cost of one spray $=\$ 93$ per ha.

${ }^{y}$ Significant percent increase in marketable fruit compared with the Copper Model (2000) or calendar spray schedule; NS = no significant difference.

${ }^{\mathrm{z}}$ Additional net profit/ha (+) or loss (-) in US\$ compared with the Copper Model (2000) or calendar spray schedule (2001); profit or loss calculated based on the following formula: [\% increase in fresh fruit] $\times$ [profit/ha when $1 \%$ of fruit moved from processing to fresh] - [cost of spray/ha] $\times$ [number of additional sprays].
The threshold chosen in this location was low and, had we chosen a threshold ence 50 and 100 points, we may have achieved control as good as the standard and saved some sprays. In Lake each, and there were no differences in Immokalee.

In Lake Alfred and Frostproof, using the Alt 100 produced the same level of control as the calendar schedule with one less spray, for a saving of $\$ 93$ per ha in each ene calendar schedule both used the fewest sprays and performed equally well.

olds provided better control with fewer sprays and proved more profitable than use of the Copper Model (7) at all four locations in 2000. In 2001, the recommended 列 in two locations, equally profitable as the calendar schedule in one location, and not profitable in one location. The calendar schedule in 2001 appeared to be more effective than the Copper Model in 2000.

The Alter-Rater works well and is espeuseful in the extremes of the weather Alter-Rater points would take much to accumulate to the threshold and, as a result, the total number of sprays would be reduced. In such locations that experience proportion of drier days, a greater seasons when there are many warm, wet days or many days with extended periods of dew, the Alter-Rater would predict more the standard but, as a result, extra spray costs would be offset by the increase in pack-out of fresh fruit.

The Copper Model may have been ineffective for controlling Alternaria brown control of melanose on fruit and uses the rainfall events to predict the need for applications (7). For Alternaria brown spot, any rainfall event over $2.5 \mathrm{~mm}$ is sufficient for inocuold resulted in saving of one application number of reasons. First, the Copper Model was designed primarily for 
lum to develop and for infection to occur, assuming sufficient duration of wetness (21). Thus, amount of rainfall does not play as important a role in the Alternaria brown spot infection cycle as the number of rain events. Nevertheless, if there were copper residues remaining, the fruit should have been protected. Second, the Copper Model treatment received one more automatic spray than the Alter-Rater at petal fall in addition to the spring flush spray that was applied to all treatments. The petal fall spray may not be necessary, especially in groves with low disease pressure on less susceptible cultivars or in weather that does not favor disease development.

The Alter-Rater model has the advantage that its thresholds can be adjusted to suit the conditions in a particular grove. A grower, experienced with a particular grove situation, is aware of prevailing disease levels and general weather conditions over the course of many years and can modify threshold levels to best suit individual groves. Since our experience with the disease history of the groves was limited, our choice of thresholds was not finely tuned to each grove. Nevertheless, the Alter-Rater proved to be effective and provided very good control in most of the groves. The Alter-Rater will help to make better-informed decisions on sprays when it is combined with grower knowledge and expertise. It is useful both in very highinoculum areas, where it can provide better control of Alternaria brown spot, and in low-inoculum areas, where extra sprays can be eliminated. The key to the success of the Alter-Rater model is the choice of threshold (21). It is an easy-to-use model, and the points can easily be calculated from temperature, rainfall, and leaf wetness data. Since it is based solely on weather factors, spray decisions can be made without need for scouting.

Although Alter-Rater provides more precision with spray timing, a grower could also modify a calendar spray program based on the prevailing weather conditions. If rainfall is high and temperatures warm, a grower could decide to spray sooner rather than later. Extended periods of dew also play a very important role in disease development but, with the calendar schedule, dew is not taken into account. Even on days with no rainfall, there may be significant leaf wetness caused by dew. On such occasions, the Alter-Rater model would be able to predict a timely spray and prevent or greatly reduce infection levels better than would the calendar schedule.

The Alter-Rater model is available publicly on the University of Florida Automated Weather Network (FAWN), and through private providers of weather data.

\section{LITERATURE CITED}

1. Canihos, Y., Peever, T. L., and Timmer, L. W. 1999. Temperature, leaf wetness, and isolate effects on infection of Minneola tangelo leaves by Alternaria sp. Plant Dis. 83:429-433.

2. Filajdíc, N., and Sutton, T. B. 1992. Influence of temperature and wetness duration on infection of apple leaves and virulence of different isolates of Alternaria mali. Phytopathology 82:1279-1283.

3. Florida Agricultural Statistics Service. 2002. Citrus Summary, 2000-01. U. S. Department of Agriculture, Agricultural Marketing Service, National Agricultural Statistics Service, Orlando, FL.

4. Franc, G. D., Harrison, M. D., and Lahmann, L. K. 1988. A simple degree-day model for initiating chemical control of potato early blight in Colorado. Plant Dis. 72:851-854.

5. Gillespie, T. J., and Sutton, J. C. 1979. A predictive scheme for timing fungicide applications to control Alternaria leaf blight in carrots. Can. J. Plant Pathol. 1:95-99.

6. Kohmoto, K., Scheffer, R. P., and Whiteside, J. O. 1979. Host selective toxins from Alternaria citri. Phytopathology 69:667-671.

7. Lin, N., Beck, H. W., Zazueta, F., Albrigo, G., Wheaton, A., Castle, B., Peart, R., Valiente, J., Martsolf, D., Ferguson, J., and Spyke, P. 1999. Decision information systems for citrus: Software implementation and testing. Proc. Fla. State Hort. Soc. 112:40-43.

8. Madden, L., Pennypacker, S. P., and McNab, A. A. 1978. FAST, a forecast system for Alternaria solani on tomato. Phytopathology 68:1354-1358.

9. Montesinos, E., Moragregra, C., Llorente, I., Vilardel, P., Bonaterra, A., Ponti, I., Bugiani, R., Cavanni, P., and Brunelli, A. 1995. Development and evaluation of an infection model for Stemphylium vesicarium on pear based on temperature and wetness duration. Phytopathology 85:586-592.

10. Muraro, R. P. 2001. 2000-2001 Comparative citrus budgets. Publ. No. FE 293. University of Florida, IFAS, EDIS, Gainesville.
11. Peever, T. L., Ibáñez, A., Akimitsu, K., and Timmer, L. W. 2002. Worldwide phylogeny of the citrus brown spot pathogen, Alternaria alternata. Phytopathology 92:794-802.

12. Peever, T. L., Su, G., Carpenter-Boggs, L. and Timmer, L. W. Molecular systematics of citrus-associated Alternaria spp. Mycologia. In press.

13. Pegg, K. G. 1966. Studies of a strain of Alternaria citri Pierce, the causal organism of brown spot of Emperor mandarin. Qld. J. Agric. Anim. Sci. 23:14-18.

14. Rotem, J. 1994. The Genus Alternaria. Biology, Epidemiology, and Pathogenicity. American Phytopathological Society Press, St. Paul, MN.

15. Simmons, E. G. 1999. Alternaria themes and variations (226-235): Classification of citrus pathogens. Mycotaxon 70:263-323.

16. Solel, Z. 1991. Alternaria brown spot on Minneola tangelo in Israel. Plant Pathol. 40:145-147.

17. Timmer, L. W., and Peever, T. L. 1997. Managing Alternaria brown spot. Citrus Ind. 78:24-25.

18. Timmer, L. W., Solel, Z., Gottwald, T. R., Ibáñez, A. M., and Zitko, S. E. 1998. Environmental factors affecting production, release, and field production of conidia of Alternaria alternata, the cause of brown spot of citrus. Phytopathology 78:1218-1223.

19. Timmer, L. W. 1999. Diseases of fruit and foliage. Pages 107-115 in: Citrus Health Management. L. W. Timmer, and L. W. Duncan, eds. American Phytopathological Society Press, St. Paul, MN.

20. Timmer, L. W., Solel, Z., and Orozco-Santos, M. 2000. Alternaria brown spot of mandarins. Pages 19-21 in: Compendium of Citrus Diseases, L. W. Timmer, S. M. Garnsey, and J. H. Graham, eds. American Phytopathological Society Press, St. Paul, MN.

21. Timmer, L. W., Darhower, H. M., Zitko, S. E., Peever, T. L., Ibáñez, A. M., and Bushong, P. M. 2000. Environmental factors affecting the severity of Alternaria brown spot of citrus and their potential use in timing fungicide applications. Plant Dis. 84:638-643.

22. Timmer, L. W., Roberts, P. D., and Chung, K. R. 2003. Alternaria brown spot. Pages 81-83 in: Florida Citrus Pest Management Guide. Publication no. SP-43. L. W. Timmer, ed. University of Florida Cooperative Extension Service, Gainesville, FL.

23. Waggoner, P. E., and Horsfall, J. A. 1969. EPIDEM: A simulator of plant disease written for a computer. Connecticut Agricultural Experiment Station Bulletin No. 698, New Haven, CT.

24. Whiteside, J. O. 1976. A newly recorded Alternaria-induced brown spot disease on Dancy tangerines in Florida. Plant Dis. Rep. 60:326-329. 